\begin{tabular}{c|cc}
$\begin{array}{c}\text { ADVANCE RESEARCH JOURNAL OF SOCIAL SCIENCE } \\
\text { Volume } 8 \mid \text { Issue } 2 \mid \text { December, 2017 |365-369 }\end{array}$ & $\begin{array}{c}\text { e ISSN-2231-6418 } \\
\text { REVIEw }\end{array}$ \\
DOI: 10.15740/HAS/ARJSS/8.2/365-369 & visit us : www.researchjournal.co.in
\end{tabular}

\title{
Iron deficiency anemia: a hematological disorder influencing reproductive age women
}

Swati Rai* and Sunita Mishra

Department of Human Development and Family Studies, School for Home Sciences, Babasaheb Bhimrao Ambedkar University, LUCKNOW (U.P.) INDIA

(Email: swati.rai77@gmail.com)

\section{ARTICLE INFO :}

$\begin{array}{lll}\text { Received } & : & 13.10 .2017 \\ \text { Accepted } & : & 23.11 .2017\end{array}$

\section{KEY WORDS :}

Anemia, Iron deficiency, Morbidity, Mortality, Prevalence, Reproductive age

\section{HOW TO CITE THIS ARTICLE :}

Rai, Swati and Mishra, Sunita (2017). Iron deficiency anemia: a hematological disorder influencing reproductive age women. Adv. Res. J. Soc. Sci., 8 (2) : 365 369, DOI: 10.15740/HAS/ARJSS/8.2/ 365-369.

*Author for correspondence

\begin{abstract}
Anemia is a leading public health problem that contributes substantially to women's health even today. Prevalence of anemia is very high in vulnerable groups especially in children and women of reproductive age. However, it is more evident in pregnant women and young girls. Reproductive age is a period where remarkable growth changes occurs necessitating optimum nutrition requirement. Anemia has been known to be responsible for a number of maternal and fetal complications. Iron deficiency anemia (IDA) is one of the most common anemia with high prevalence rate. In India, national and regional surveys, estimates that the prevalence of anemia could be as high as 74 per cent in children below three years of age, $85 \%$ in expectant mothers and 90 per cent among adolescent girls in some population groups. Anemia is the second most common cause of maternal death in India accounting for $20 \%$ of total maternal deaths. Due to IDA, women are at increased risk of preterm delivery and low birth weight which eventually leads to behavioural and affective disorder in children. The aim of this review focuses on the prevalence of IDA and its influence on young women and maternal health.
\end{abstract}

